\title{
ANALISIS DESAIN AKUSTIK RUANG KELAS UNIFA DALAM MENINGKATKAN KUALITAS BELAJAR MENGAJAR
}

\author{
Meldawati Artayani ${ }^{1}$, Noviar Nurdin Kasim ${ }^{2}$ \\ ${ }^{1,2}$ Prodi Arsitektur, Fakultas Teknik, Universitas Fajar
}

\begin{abstract}
Abstrak
Kebisingan merupakan hal yang mengganggu dalam proses belajar mengajar, pada intensitas yang lama dan tingkat tertentu dapat berbahaya bagi kesehatan. Tingkat kebisingan dari suatu lokasi yang berlebihan dapat memiliki macam dampak negatif pada orang yang sering bersinggungan langsung seperti gangguan pendengaran, kenyamanan, kurang konsentrasi dan gangguan emosi. Penelitian ini memusatkan kajian pada faktor penyusun material akustik yang mempengaruhi kebisingan dalam ruang kelas, sedangkan peningkatan kualitas proses belajar mengajar didasarkan pada kenyamanan penghuni. Tujuan utama penelitian yaitu untuk menganalisis intensitas tingkat kebisingan didalam ruang kelas belajar universitas Fajar yang disebabkan oleh pengunaan material penyusun ruangan dan membandingkan nilai yang diperoleh dengan ambang baku tingkat kebisingan berdasar KMLH Kep-48/MENLH/1996 25 November 1996, serta memberikan alternatif pemecahan masalah. Penelitian ini merupakan penelitian eksperimental dengan menggunakan analisis statistic sederhana yaitu mengadakan pengamatan langsung dilapangan (Ruang Kelas C 205, C 208 dan Ruang Kelas D207) dan pelaporan secara seksama, teliti, sistematis dan akurat mengenai keadaan akustik ruangan. Pengambilan data mengunakan alat sound level meter dan hasilnya rata-rata kemudian dilakukan perhitungan dan evaluasi.
\end{abstract}

Kata kunci: Ruang Kelas, Material Akustik

\begin{abstract}
Noise is disturbing in teaching and learning, at a long intensity and a certain level can be harmful to health. The level of noise from an excessive location can have a kind of negative impact on people who often touch directly like hearing loss, comfort, lack of concentration and emotional disturbance. This study focuses on the study of acoustic material factors that affect noise in the classroom, while improving the quality of teaching and learning process is based on the comfort of the residents. The main objective of the study was to analyze the intensity of noise level within the classroom of the Dawn university classroom which was caused by the use of the room compiler material and compare the values obtained with the standard noise level threshold based on KMLH Kep-48 / MENLH / 1996 November 25, 1996, and provide an alternative problem solving. This research is an experimental research using simple statistical analysis that is conducting direct observation in the field (Classroom C 205, C 208 and Classroom D207) and reporting carefully, thoroughly, systematically and accurately on the acoustic condition of the room. Data retrieval using sound level meter tool and the result is then calculated and evaluated.
\end{abstract}

\section{Keywords: Classroom, Acoustic Material}

\section{PENDAHUUAN}

Terciptanya iklim belajar yang baik didukung dengan adanya usaha dalam mengatur segala hal dalam proses pembelajaran, seperti lingkungan fisik dan sistem pembelajaran di kelas. Pembelajaran yang efektif membutuhkan kondisi kelas yang kondusif. Kelas yang kondusif adalah lingkungan belajar yang mendorong terjadinya proses belajar yang intensif dan efektif. Strategi belajar apapun yang ditempuh dosen akan menjadi tidak efektif jika tidak didukung dengan iklim dan kondisi kelas yang kondusif. Oleh karena itu dosen perlu menata dan mengelola lingkungan belajar di kelas sedemikian rupa sehingga menyenangkan, aman, dan menstimulasi setiap anak agar terlibat secara maksimal dalam proses pembelajaran. Intisari dari pendidikan adalah pembelajaran dimana umumnya aktivitas yang dilakukan adalah penyaluran informasi dan ilmu pengetahuan dari pengajar ke pelajar. Belajar tidak dipengaruhi oleh faktor internal saja, tetapi juga dipengaruhi oleh faktor eksternal, yaitu kondisi lingkungan sekitarnya. Djunaedi (2003) mengungkapkan ada dua syarat agar pelajar dapat mendengarkan pelajaran dengan baik, pertama, lingkungan yang tidak bising.

Bising latar belakang dapat bersumber dari lalu lintas di jalan, aktivitas di sekitar sekolah, suara dari kelas sebelah dan bising dari mesin penyejuk udara. Kedua adalah waktu dengung yang rendah. Waktu dengung adalah ukuran yang menunjukkan seberapa cepat suara akan menghilang semakin tinggi waktu dengung akan semakin lama suara itu bertahan di dalam ruangan. Dua kriteria yang digunakan oleh ANSI-SI2.60 (Standar Kualitas Akustik Bangunan pendidikan/sekolah) untuk mematok kualitas akustik ruang kelas. Pertama bising lingkungan tidak boleh 
melebihi $35 \mathrm{dBA}$ dan $55 \mathrm{dBC}$ diseluruh bagian ruang kelas (dBA dan $\mathrm{dBC}$ adalah satuan kekuatan suara yang sudah memperhitungkan kandungan frekuensi sumber suara). Kedua, waktu dengung yang tidak boleh lebih dari 0,6 detik.

Kebisingan merupakan hal yang mengganggu dalam proses belajar mengajar, pada intensitas yang lama dan tingkat tertentu dapat berbahaya bagi kesehatan. Tingkat kebisingan dari suatu lokasi yang berlebihan dapat memiliki macam dampak negatif pada orang yang sering bersinggungan langsung seperti gangguan pendengaran, kenyamanan, kurang konsentrasi dan gangguan emosi. Beberapa hasil penelitian mengungkapkan bahwa semakin tinggi tingkat bising di ruang kelas, maka semakin rendah konsentrasi belajar siswa pada kelas tersebut dan sebaliknya semakin rendah tingkat kebisingan ruang kelas, maka akan semakin tinggi konsentrasi belajar siswa (Hananto, 2009). Hal inilah yang menunjukkan bahwa, kajian akustik ruang kelas merupakan hal yang sangat penting dilakukkan.

Penelitian ini memusatkan kajian pada faktor penyusun material akustik yang mempengaruhi kebisingan dalam ruang kelas, sedangkan peningkatan kualitas proses belajar mengajar didasarkan pada kenyamanan penghuni. Tujuan utama penelitian yaitu untuk menganalisis intensitas tingkat kebisingan didalam ruang kelas belajar universitas Fajar yang disebabkan oleh pengunaan material penyusun ruangan dan membandingkan nilai yang diperoleh dengan ambang baku tingkat kebisingan berdasar KMLH Kep-48/MENLH/1996 25 November 1996, serta memberikan alternatif pemecahan masalah.

\section{ISI PENELITIAN}

\subsection{Metode}

Pembahasan pada bab ini berupa analisis perbaikan kualitas akustik dalam ruang kelas C 205, C 208 dan D 207, namun sebelumnya akan dibahas terlebih dahulu hasil pengambilan data kualitas akustik ruang kelas pada kondisi awal dan setelah terjadi perlakuan untuk melihat nilai RT (Reverberation Time) dan TL (Transmission Loss) ruangan. Langkah selanjutnya yaitu merekomendasikan pemilihan bahan/material pelapis guna menyelesaikan permasalahan akustik yang terdapat didalam ruang kelas.

\subsection{Hasil}

\subsubsection{Pengukuran Dimensi Ruang}

Pengukuran RT dan TL dalam ruang kelas dilaksanakan pada dua gedung yang berbeda dengan volume ruang yang berbeda. Hasil pengukuran ruang kelas didapatkan ruang C 205 memiliki $202.88 \mathrm{~m}^{2}$ partisi dengan volume sebesar $114.19 \mathrm{~m}^{3}$, ruang C 208 memiliki $191.19 \mathrm{~m}^{2}$ partisi dengan volume sebesar $106.13 \mathrm{~m}^{3}$ dan ruang D 207 memiliki 149.46 $\mathrm{m}^{2}$ partisi serta volume sebesar $86.52 \mathrm{~m}^{3}$. Hasil pengukuran dimensi ruang kelas terangkum dalam tabel 3. Data dari hasil pengukuran menunjukkan bahwa ruang kelas C 205 memiliki volume serta luasan partisi terbesar sedangkan ruang kelas D 207 memiliki volume dan luasan partisi terkecil dalam pengukuran ini. Adapun material yang terdapat dalam ruang kelas rata-rata berbahan gypsum, bata plester, papan kayu, kaca dan aluminium.

Tabel 1. Data pengukuran dimensi ruang kelas

\begin{tabular}{|c|c|c|c|c|}
\hline $\begin{array}{l}\text { Ruang } \\
\text { Kelas }\end{array}$ & Sisi & Elemen & $\begin{array}{c}\text { Luasan } \\
\text { Partisi } \\
\text { (m2) }\end{array}$ & $\begin{array}{c}\text { Volume } \\
\text { Ruang } \\
\text { (m3) }\end{array}$ \\
\hline \multirow{9}{*}{ C 205} & \multirow[t]{2}{*}{ Depan } & $\begin{array}{l}\text { Dinding } \\
\text { Partisi }\end{array}$ & 12.80 & \multirow{9}{*}{114.19} \\
\hline & & Pintu & 1.60 & \\
\hline & $\begin{array}{l}\text { Samp. } \\
\text { Kiri }\end{array}$ & $\begin{array}{l}\text { Dinding } \\
\text { Partisi }\end{array}$ & 19.83 & \\
\hline & $\begin{array}{l}\text { Samp. } \\
\text { Kanan }\end{array}$ & $\begin{array}{l}\text { Dinding } \\
\text { Bata }\end{array}$ & 19.83 & \\
\hline & \multirow[t]{2}{*}{ Belakang } & $\begin{array}{l}\text { Dinding } \\
\text { Partisi }\end{array}$ & 7.49 & \\
\hline & & Jendela & 6.91 & \\
\hline & Atas & Plafond & 45.68 & \\
\hline & Bawah & Lantai & 45.68 & \\
\hline & & Total & 202.88 & \\
\hline \multirow{9}{*}{ C 208} & \multirow[t]{2}{*}{ Depan } & $\begin{array}{l}\text { Dinding } \\
\text { Partisi }\end{array}$ & 10.04 & \multirow{9}{*}{106,13} \\
\hline & & Pintu & 1.89 & \\
\hline & $\begin{array}{l}\text { Samp. } \\
\text { Kiri }\end{array}$ & $\begin{array}{l}\text { Dinding } \\
\text { Partisi }\end{array}$ & 23.59 & \\
\hline & $\begin{array}{l}\text { Samp. } \\
\text { Kanan }\end{array}$ & $\begin{array}{l}\text { Dinding } \\
\text { Bata }\end{array}$ & 23.59 & \\
\hline & \multirow[t]{2}{*}{ Belakang } & $\begin{array}{l}\text { Dinding } \\
\text { Partisi }\end{array}$ & 6.08 & \\
\hline & & Jendela & 5.85 & \\
\hline & Atas & Plafond & 40.05 & \\
\hline & Bawah & Lantai & 40.05 & \\
\hline & & Total & 191.19 & \\
\hline \multirow{9}{*}{ D 207} & \multirow[t]{2}{*}{ Depan } & $\begin{array}{l}\text { Dinding } \\
\text { Partisi }\end{array}$ & 16.32 & \multirow{9}{*}{86.52} \\
\hline & & Pintu & 1.68 & \\
\hline & $\begin{array}{l}\text { Samp. } \\
\text { Kiri }\end{array}$ & $\begin{array}{l}\text { Dinding } \\
\text { Partisi }\end{array}$ & 14.42 & \\
\hline & $\begin{array}{l}\text { Samp. } \\
\text { Kanan }\end{array}$ & $\begin{array}{l}\text { Dinding } \\
\text { Partisi }\end{array}$ & 14.42 & \\
\hline & \multirow[t]{2}{*}{ Belakang } & $\begin{array}{l}\text { Dinding } \\
\text { Bata }\end{array}$ & 10.56 & \\
\hline & & Jendela & 2.64 & \\
\hline & Atas & Plafond & 29.42 & \\
\hline & Bawah & Lantai & 30.00 & \\
\hline & & Total & 149.46 & \\
\hline
\end{tabular}

Sumber : Analisis Penulis

\subsubsection{Data Pengukuran Kualitas Akustik Ruang Kelas (C 205, C 208, D 207)}

Pengukuran kualitas akustik ruang kelas dengan memperhatikan waktu dengung (RT) yang telah diukur. Pengukuran ini dilaksanakan pengulangan sebanyak dua kali maka diperoleh hasil pengukuran waktu dengung (RT) yang beragam dari masingmasing ruang kelas. Pada ruang kelas C 205 waktu 
dengung (RT) tertinggi sebesar 2.51 detik pada waktu siang hari dan nilai terendah sebesar 1.18 detik saat pagi hari. Ruang kelas C 208 waktu dengung (RT) tertinggi sebesar 2.55 detik pada waktu malam hari dan nilai terendah sebesar 1.02 detik siang hari. Sedangkan ruang kelas D 207 waktu dengung (RT) tertinggi sebesar 1.49 detik di waktu malam hari dan nilai terendah sebesar 1.08 detik saat pagi hari. Keseluruhan nilai hasil pengukuran waktu dengung (RT) ruang kelas dapat dilihat dalam tabel 4. Nilai waktu dengung (RT) tertinggi terdapat pada ruang kelas C 208 sebesar 2.55 detik dan nilai waktu dengung (RT) terendah pada ruang kelas C 208 yaitu sebesar 1.02 detik.

Tabel 2. Pengukuran Waktu Dengung (RT) Ruang Kelas

\begin{tabular}{|c|c|c|c|c|}
\hline \multirow[b]{2}{*}{$\begin{array}{l}\text { Ruang } \\
\text { Kelas }\end{array}$} & \multirow{2}{*}{$\begin{array}{c}\text { Waktu } \\
\text { Dengung } \\
\text { Perhitungan } \\
\text { (s) }\end{array}$} & \multicolumn{3}{|c|}{$\begin{array}{l}\text { Waktu Dengung (s) } \\
\text { Pengukuran }\end{array}$} \\
\hline & & $\begin{array}{c}\text { Pagi } \\
(08.00 \\
\text { wita }) \\
\end{array}$ & $\begin{array}{l}\text { Siang } \\
(13.00 \\
\text { wita }) \\
\end{array}$ & $\begin{array}{c}\text { Malam } \\
(17.00 \\
\text { wita }) \\
\end{array}$ \\
\hline C 205 & 0.32 & $01: 18$ & $02: 51$ & $01: 30$ \\
\hline C208 & 0.50 & $01: 14$ & 01:02 & $02: 55$ \\
\hline D 207 & 0.53 & 01: 08 & $01: 30$ & $01: 49$ \\
\hline
\end{tabular}

Sumber : Analisis Penulis

Data pengukuran selanjutnya yaitu kehilangan transmisi (Transmision Lost/TL), kehilangan transmisi didapat dari perhitungan menggunakan rumus 2.2 dan 2.3. Perhitungan koefisiensi serap masing-masing partisi serta luasan partisinya ditunjukkan dalam tabel 6 , adapun nilai koefisien serap bahan diambil hanya pada frekuensi $500 \mathrm{~Hz}$ saja, karena frekuensi ini dipakai sebagai rerata koefisien absorsi material pada umumnya. Sedangkan perhitungan nilai NR (Noise Reduction) dan hasil perhitungan nilai TL (Transmision Lost) terangkum dalam tabel 5 dibawah ini.

Tabel 3. Nilai NR (Noise Reduction) dan TL (Transmision Lost) ruang kelas

\begin{tabular}{|c|c|c|c|c|c|c|}
\hline \multirow{2}{*}{ 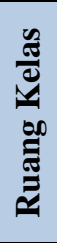 } & \multirow{2}{*}{$\frac{\sum}{\frac{E}{\pi}}$} & \multirow{2}{*}{$\begin{array}{c}\text { Sour } \\
\text { ce } \\
\text { Roo } \\
\text { m } \\
\mathbf{P}_{1} \\
\text { (dB) }\end{array}$} & \multicolumn{2}{|c|}{$\begin{array}{l}\text { NR (Noise } \\
\text { Reduction) }\end{array}$} & \multicolumn{2}{|c|}{$\begin{array}{c}\text { TL } \\
\text { Perhitungan }\end{array}$} \\
\hline & & & $\begin{array}{l}\mathbf{L p _ { 2 }} \\
(\mathrm{dB})\end{array}$ & $\begin{array}{l}L p_{3} \\
(d B)\end{array}$ & $\begin{array}{l}\mathbf{L p _ { 2 }} \\
(\mathbf{d B})\end{array}$ & $\begin{array}{l}L p_{3} \\
(d B)\end{array}$ \\
\hline \multirow{2}{*}{ 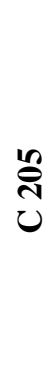 } & 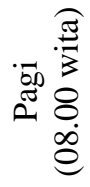 & 94.82 & $\frac{\stackrel{N}{n}}{m}$ & $\frac{m}{\stackrel{n}{d}}$ & $\begin{array}{l}\stackrel{\circ}{\sim} \\
\stackrel{\sim}{\sim}\end{array}$ & $\frac{\bar{m}}{\stackrel{m}{n}}$ \\
\hline & 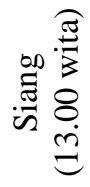 & 95.60 & $\begin{array}{l}\stackrel{N}{n} \\
\ddot{n}\end{array}$ & $\frac{n}{n}$ & 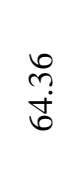 & $\underset{\stackrel{\infty}{+}}{\stackrel{9}{+}}$ \\
\hline
\end{tabular}

\begin{tabular}{|c|c|c|c|c|c|c|}
\hline & 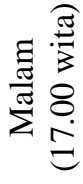 & 94.98 & $\begin{array}{l}\infty \\
\text { i } \\
\text { ñ }\end{array}$ & $\begin{array}{l}\text { o } \\
\text { ஸे }\end{array}$ & $\begin{array}{l}\bar{\sigma} \\
\hat{\sigma}\end{array}$ & $\begin{array}{l}\infty \\
\infty \\
\dot{m} \\
\dot{m}\end{array}$ \\
\hline \multirow{3}{*}{ ્ֻతి } & 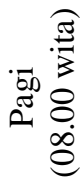 & 93.32 & $\frac{n}{\mathscr{7}}$ & $\begin{array}{l}\tilde{n} \\
\text { o } \\
\stackrel{\sim}{N}\end{array}$ & $\begin{array}{l}\text { مे } \\
\text { in }\end{array}$ & $\begin{array}{l}\text { ○ } \\
\text { ○े }\end{array}$ \\
\hline & 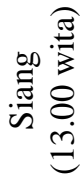 & 96.58 & $\begin{array}{l}\tilde{n} \\
\tilde{n} \\
\tilde{n}\end{array}$ & $\begin{array}{l}\infty \\
\stackrel{\infty}{+} \\
\text { ñ }\end{array}$ & 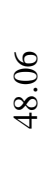 & ণิ \\
\hline & 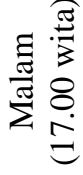 & 95.60 & $\begin{array}{l}\text { ơ } \\
\text { N }\end{array}$ & $\hat{n}$ & $\begin{array}{l}\text { ⿵ె } \\
\dot{+}\end{array}$ & \begin{tabular}{l}
\multirow{2}{n}{} \\
n̊
\end{tabular} \\
\hline \multirow{3}{*}{$\hat{\text { ิે }}$} & 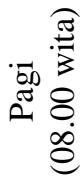 & 91.23 & $\vec{r}$ & $\begin{array}{l}\text { ñ } \\
\text { ָे }\end{array}$ & $\begin{array}{l}\text { I } \\
\infty \\
\infty\end{array}$ & $\begin{array}{l}\infty \\
\text { ஸे } \\
\text { mे }\end{array}$ \\
\hline & 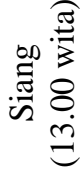 & 90.43 & $\frac{n}{\stackrel{\sim}{f}}$ & $\begin{array}{l}\stackrel{\Omega}{\Omega} \\
\infty \\
\stackrel{\sim}{1}\end{array}$ & $\begin{array}{l}= \\
n \\
n\end{array}$ & $\begin{array}{l}\infty \\
\text { Ð } \\
\end{array}$ \\
\hline & 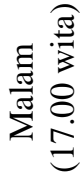 & 89.27 & 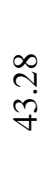 & $\frac{N}{N}$ & $\begin{array}{l}\text { ปे } \\
\text { ڤn }\end{array}$ & $\begin{array}{l}\infty \\
0 \\
0 \\
\dot{\gamma}\end{array}$ \\
\hline
\end{tabular}

Sumber : Analisis Penulis

Hasil perhitungan nilai NR (Noise Reduction) ruang kelas didapat nilai tertinggi untuk titik ukur P2 (Selasar ruangan) pada ruang kelas C205 sebesar $53.32 \mathrm{~dB}$ dan nilai terendah di ruang C208 sebesar 27.28 dB. Sedangkan nilai NR titik ukur P3 (ruang penerima) didapat nilai tertinggi sebesar $37.15 \mathrm{~dB}$ dan nilai terendah sebesar $22.13 \mathrm{~dB}$ pada ruang yang sama C204. Nilai TL (Transmision Lost) dari hasil perhitungan didapatkan nilai TL tertinggi untuk titik ukur P2 (Selasar ruangan) pada ruangan C205 sebesar 64,36 dB dan nilai terendah sebesar 40,63 dB. Sedangkan pada titik ukur P3 (ruang penerima) didapatkan nilai TL tertinggi sebesar $48.19 \mathrm{~dB}$ ruang C205 dan nilai terendah sebesar $33.17 \mathrm{~dB}$ pada ruangan yang sama.

Tabel 4. Perhitungan koefisien absorsi bahan dalam ruang kelas

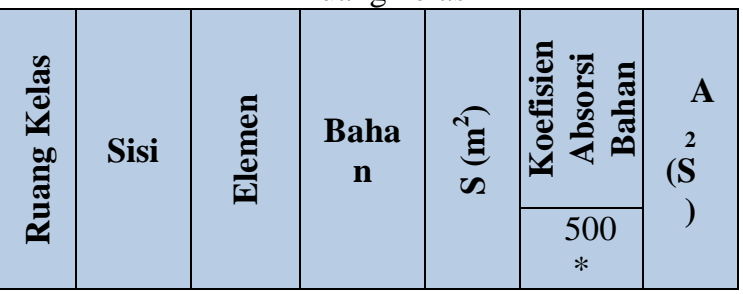




\begin{tabular}{|c|c|c|c|c|c|c|}
\hline \multirow{10}{*}{$\stackrel{\text { ป̂ }}{\text { Uิ }}$} & \multirow{2}{*}{ 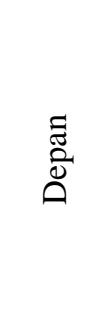 } & 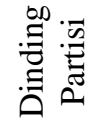 & $\begin{array}{l}\text { 志 } \\
\text { 总 } \\
\text { 总 }\end{array}$ & $\begin{array}{l}\infty \\
\stackrel{\beth}{\simeq}\end{array}$ & 0.05 & \multirow{10}{*}{$\begin{array}{l}15 \\
98\end{array}$} \\
\hline & & 胥 & 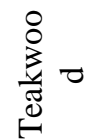 & $\stackrel{0}{-}$ & 0.17 & \\
\hline & 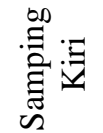 & 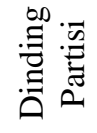 & 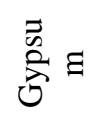 & $\begin{array}{l}\infty \\
\infty \\
\stackrel{2}{ }\end{array}$ & 0.05 & \\
\hline & 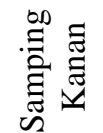 & 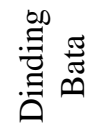 & 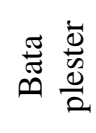 & $\begin{array}{l}\infty \\
\infty \\
\ddot{2}\end{array}$ & 0.02 & \\
\hline & \multirow{3}{*}{ 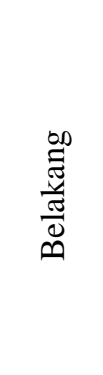 } & 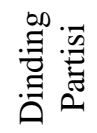 & 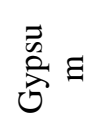 & $\stackrel{\cong}{\Xi}$ & 0.05 & \\
\hline & & \multirow{2}{*}{$\begin{array}{l}\frac{\pi}{0} \\
\frac{0}{0} \\
\stackrel{0}{0}\end{array}$} & 祃 & $\bar{n}$ & 0.10 & \\
\hline & & & $\underset{\mathscr{\Xi}}{\tilde{\Xi}}$ & $\begin{array}{l}\hat{6} \\
i\end{array}$ & 0.01 & \\
\hline & 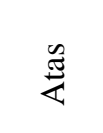 & $\begin{array}{l}\vec{\Xi} \\
\frac{\vec{D}}{\tilde{D}} \\
\frac{\pi}{2}\end{array}$ & 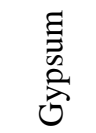 & $\begin{array}{l}\infty \\
\stackrel{\infty}{\circ} \\
\dot{f}\end{array}$ & 0.05 & \\
\hline & \multirow{2}{*}{ 胥 } & \multirow{2}{*}{ 急 } & 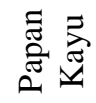 & $\begin{array}{l}\infty \\
\stackrel{\infty}{\circ} \\
\dot{f}\end{array}$ & 0.10 & \\
\hline & & & 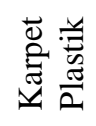 & $\begin{array}{l}\infty \\
\dot{b} \\
\dot{f}\end{array}$ & 0.01 & \\
\hline \multirow{5}{*}{ 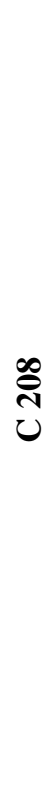 } & \multirow{2}{*}{ 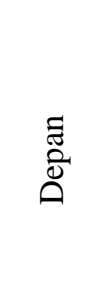 } & 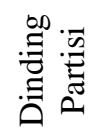 & 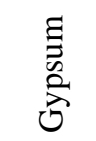 & $\begin{array}{l} \pm \\
\stackrel{0}{0}\end{array}$ & 0.05 & \multirow{5}{*}{$\begin{array}{l}10 \\
02\end{array}$} \\
\hline & & $\stackrel{\Xi}{\Xi}$ & 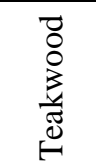 & 1.89 & 0.17 & \\
\hline & 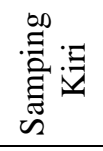 & 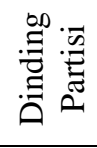 & $\sum_{\mathcal{W}}^{\vec{D}} \Xi$ & $\begin{array}{c}23 . \\
59\end{array}$ & 0.05 & \\
\hline & 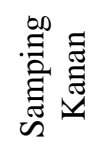 & 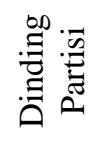 & $\begin{array}{l}\Xi \\
\text { 荧 } \\
\text { م્ }\end{array}$ & जे & 0.05 & \\
\hline & 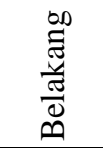 & 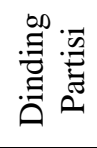 & 总 & $\stackrel{\infty}{0}$ & 0.05 & \\
\hline
\end{tabular}

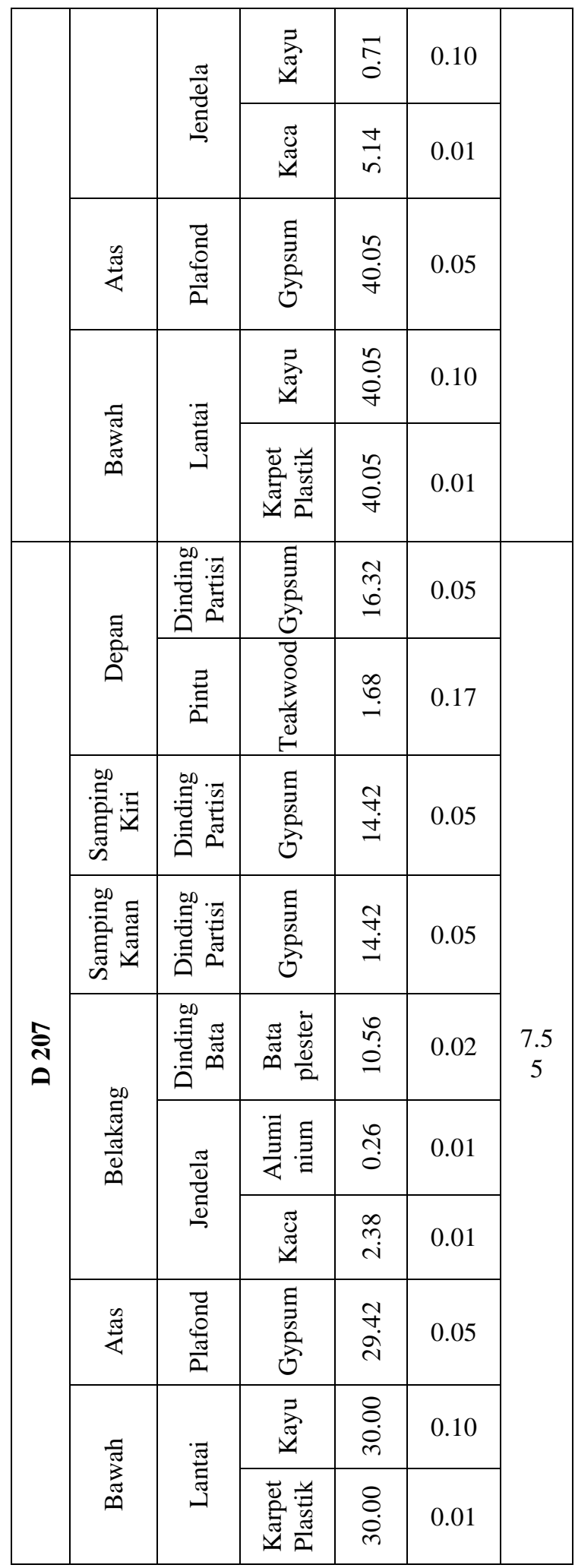

*Frekuensi $500 \mathrm{~Hz}$ dipakai sebagai rerata koefisien absorsi material pada umumnya

2.2.3 Peningkatan Kualitas Akustik Ruang Kelas Peningkatan kualitas akustik pada ruang kelas C205, C208 dan D207 dapat ditempuh dengan beberapa pilihan material akustik. Perbaikan nilai waktu degung (RT) masing-masing kelas disimulasikan dengan memberikan penambah material penyerap 
suara pada lantai berupa karpet lantai. Beberapa pilihan karpet beserta karateristik peredaman suaranya dapat dilihat dalam tabel 7. Adapun hasil dari simulasi penggunaan karpet pada lantai untuk memenuhi kebutuhan standar waktu dengung ruang kelas C205, C208 dan D207 dapat dilihat dalam tabel 8 .

Tabel 5. Material lantai sebagai peredam suara pada masing-masing frekuensi

\begin{tabular}{|c|c|c|c|c|c|c|}
\hline Materia & \multicolumn{5}{|c|}{ Frekuensi } \\
\cline { 2 - 7 } 1 Lantai & $\mathbf{1 2 5}$ & $\mathbf{2 5 0}$ & $\mathbf{5 0 0}$ & $\begin{array}{c}\mathbf{1 0 0} \\
\mathbf{0}\end{array}$ & $\begin{array}{c}\mathbf{2 0 0} \\
\mathbf{0}\end{array}$ & $\begin{array}{c}\mathbf{4 0 0} \\
\mathbf{0}\end{array}$ \\
\hline $\begin{array}{c}\text { Karpet } \\
\text { Berat } \\
\text { diatas } \\
\text { beton }\end{array}$ & $\begin{array}{c}0.0 \\
2\end{array}$ & $\begin{array}{c}0.0 \\
6\end{array}$ & $\begin{array}{c}0.1 \\
4\end{array}$ & 0.06 & 0.65 & 0.30 \\
\hline $\begin{array}{c}\text { Karpet } \\
\text { Berat } \\
\text { diatas } \\
\text { Karet } \\
\text { Busa }\end{array}$ & 0.0 & 0.2 & 0.5 & 0.71 & 0.73 & 0.55 \\
\hline $\begin{array}{c}\text { Karpet } \\
\text { berat } \\
\text { diatas } \\
\text { lateks } \\
\text { takberpo } \\
\text { ri diatas } \\
\text { karet } \\
\text { busa }\end{array}$ & 0.0 & 0.2 & 0.3 & 0.48 & 0.63 & 0.35 \\
\hline $\begin{array}{c}\text { Karpet } \\
\text { ruang } \\
\text { dalam- } \\
\text { ruang } \\
\text { luar }\end{array}$ & 0.0 & 0.0 & 0.2 & 0.45 & 0.65 & 0.20 \\
\hline
\end{tabular}

Tabel 6. Hasil simulasi perhitungan penambahan bahan penyerap suara pada masing-masing lantai ruang kelas

\begin{tabular}{|c|c|c|c|c|c|}
\hline \multirow{2}{*}{ } & \multirow{2}{*}{ 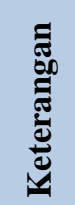 } & \multirow{2}{*}{$\begin{array}{c}\begin{array}{c}\text { Koefisie } \\
\text { n serap }\end{array} \\
\alpha 500 \\
\text { Hz }^{*}\end{array}$} & \multicolumn{3}{|c|}{ Waktu dengung (s) } \\
\hline & & & $\begin{array}{c}\mathbf{C 2 0} \\
5\end{array}$ & $\begin{array}{c}\text { C20 } \\
8\end{array}$ & $\begin{array}{c}\text { D20 } \\
7\end{array}$ \\
\hline \multirow{2}{*}{$\begin{array}{l}\text { Karpet } \\
\text { Tipis } \\
\text { ruang } \\
\text { dalam- } \\
\text { ruang } \\
\text { luar }\end{array}$} & $\begin{array}{c}\Sigma S . \\
\alpha\end{array}$ & \multirow[b]{2}{*}{0.05} & 0.09 & 0.06 & 0.05 \\
\hline & $\begin{array}{c}\text { RT- } \\
60\end{array}$ & & 0.37 & 0.53 & 0.64 \\
\hline \multirow{2}{*}{$\begin{array}{l}\text { Karpet } \\
\text { Berat } \\
\text { diatas } \\
\text { beton }\end{array}$} & $\begin{array}{c}\sum \mathrm{S} . \\
\alpha\end{array}$ & \multirow{2}{*}{0.14} & 0.09 & 0.06 & 0.06 \\
\hline & $\begin{array}{c}\text { RT- } \\
60\end{array}$ & & 0.36 & 0.51 & 0.54 \\
\hline \multirow{2}{*}{$\begin{array}{c}\text { Karpet } \\
\text { Berat } \\
\text { diatas } \\
\text { Karet } \\
\text { Busa }\end{array}$} & $\begin{array}{c}\Sigma S . \\
\alpha\end{array}$ & \multirow{2}{*}{0.57} & 0.13 & 0.12 & 0.10 \\
\hline & $\begin{array}{c}\text { RT- } \\
60\end{array}$ & & 0.24 & 0.27 & 0.31 \\
\hline
\end{tabular}

\begin{tabular}{|c|c|c|c|c|c|}
\hline \multirow{2}{*}{$\begin{array}{c}\text { Karpet } \\
\text { berat } \\
\text { diatas } \\
\text { lateks } \\
\text { takberpor } \\
\text { i diatas } \\
\text { karet } \\
\text { busa }\end{array}$} & $\begin{array}{c}\Sigma S \\
\alpha\end{array}$ & \multirow[b]{2}{*}{0.34} & 0.11 & 0.09 & 0.08 \\
\hline & $\begin{array}{c}\text { RT- } \\
60\end{array}$ & & 0.29 & 0.36 & 0.41 \\
\hline \multirow{2}{*}{$\begin{array}{c}\text { Karpet } \\
\text { ruang } \\
\text { dalam- } \\
\text { ruang } \\
\text { luar }\end{array}$} & $\begin{array}{c}\sum S . \\
\alpha\end{array}$ & \multirow{2}{*}{0.20} & 0.09 & 0.07 & 0.07 \\
\hline & $\begin{array}{c}\text { RT- } \\
60\end{array}$ & & 0.34 & 0.45 & 0.49 \\
\hline
\end{tabular}

*Frekuensi $500 \mathrm{~Hz}$ dipakai sebagai rerata koefisien absorsi material pada umumnya

Perbaikan kualitas NC (Noise Criteria) dibutuhkan hasil data perhitungan TL (Transmission Lost) pada masing-masing ruang kelas untuk menentukan tebal bahan (W) yang ditambahkan pada dinding. Pengukuran dari kedua titik ukur masing-masing kelas terlihat bahwa pada titik ukur 3 (Lp3) memiliki nilai transmisi yang paling rendah hal ini berarti sumber bunyi yang memapar media dinding kurang terserap sehingga suara masuk ke ruang penerima. Dari hasil perhitungan menggunakan rumus 2.4 pada pada frekuensi $500 \mathrm{~Hz}$ maka didapatkan nilai W pada titik ukur 3 (Lp3) untuk ruang kelas C205 sebesar 114,9 Kg/m ${ }^{2}$ ruang kelas C208 sebesar 82,3 $\mathrm{Kg} / \mathrm{m}^{2}$ dan ruang kelas D207 sebesar $55,5 \mathrm{Kg} / \mathrm{m}^{2}$ untuk mengetahui seberapa tebal dinding yang akan ditambahkan maka nilai $\mathrm{W}$ akan dibagi dengan nilai kerapatan massa dinding standar yaitu $21 \mathrm{Kg} / \mathrm{m}^{2} / \mathrm{cm}$ (Darmawan,dkk). Maka ketebalan dinding yang harus ditambahkan pada dinding samping ruang kelas C205 sebesar 5,4 cm untuk ruang kelas C208 sebesar 3,9 cm dan ruang kelas D207 sebesar 2,3 $\mathrm{cm}$. Penambahan dinding samping pada masingmasing ruang kelas diharapkan akan terjadi penurunan pada nilai bising latar belakang sehingga suara tidak mempengaruhi ruang penerima lainnya.

\subsection{Pembahasan}

Perbaikan kualitas akustik dari ruang kelas C205, C208 dan D207 dapat dilaksanakan dengan melihat hasil pengukuran dan perhitungan dari performa akustik masing-masing ruang kelas. Hasil perhitungan menggunakan rumus Sabine didapat waktu dengung (RT) sebesar 0,32 detik untuk C205, dan 0,50 detik untuk C208 serta 0,53 detik untuk D207. Sedangkan untuk hasil pengukuran didapat waktu tertinggi RT masing-masing ruang kelas yaitu untuk ruang kelas C205 sebesar 02.51 detik, ruang kelas C208 sebesar 0.25 detik dan ruang kelas D207 sebesar 01.49 detik. Apabila kedua data tersebut diatas dibandingkan maka nilai deviasi yang terjadi terlalu besar, halini disebabkan karena (1) terdapat beberapa kaca jendela yang pecah keadaan ini secara langsung mempengaruhi masuknya suara luar 
kedalam ruang pengukuran, (2) waktu pengukuran merupakan jam-jam terpadat perkuliahan.

Langkah selanjutnya yang ditempuh untuk memperbaiki waktu dengung ruang kelas selain dari memperbaiki beberapa jendela kaca, yaitu dengan mengubah material pada lantai, halini dimaksudkan untuk menurunkan waktu dengung pengukuran sehingga mendekati nilai standar. Dari hasil simulasi menggunakan material pengganti pada lantai berupa karpet tipis maka didapat waktu dengung mendekati standar yaitu sebesar 0,64 detik.

Perbaikan performa akustik untuk TL (Transmission Lost) khususnya pada dinding samping ruangan. Munculnya perbedaan tekanan suara antara titik ukur Lp3 (ruang samping sumber suara) dengan titik ukur Lp2 (ruang depan sumber suara) disebabkan adanya bunyi yang berasal dari dinding-dinding samping yang menjalarkan getarangetaran pada dinding pemisah dan dari dinding pemisah baru ke dalam ruangan (gambar 3). Adapun cara untuk penaganannya, maka ketebalan dinding yang harus ditambahkan pada ruang kelas C205 sebesar 5,4 cm untuk ruang kelas C208 sebesar 3,9 $\mathrm{cm}$ dan ruang kelas D207 sebesar $2,3 \mathrm{~cm}$.

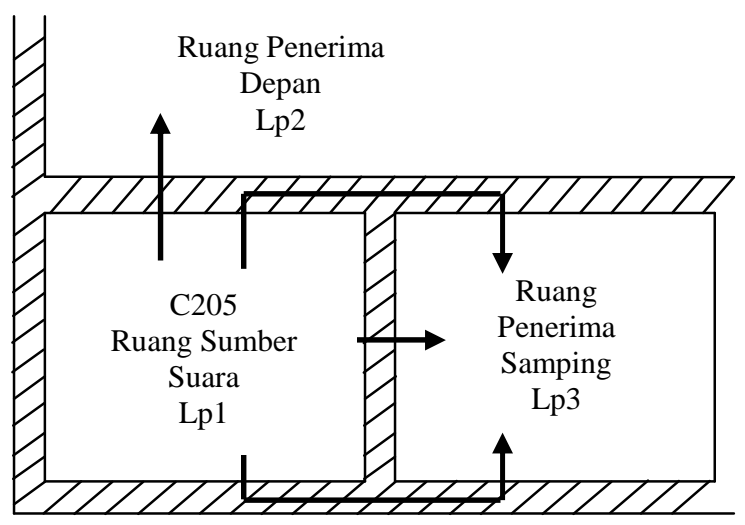

Gambar 1. Proses menjalarnya getaran suara pada dinding ruang kelas

\section{KESIMPULAN}

Performa akustik pada pengukuran masingmasing ruang kelas dimana rata-rata waktu dengung untuk ruang kelas C205 sebesar 01.88 detik, ruang kelas C208 sebesar 1.72 detik dan ruang kelas D207 sebesar 01.10 detik pada frekuensi tengan dan nilai $\mathrm{NC} 45 \mathrm{~dB}$, dimana $\mathrm{NC}$ standar ruang kelas berkisar 30-40 dB.

Menurunkan waktu dengung ruang kelas dengan memperbaiki beberapa jendela kaca, adapun material yang dapat digunakan sebagai material pengganti pada lantai berupa karpet tipis maka didapat waktu dengung mendekati standar yaitu sebesar 0,64 detik. Perbaikan performa akustik untuk TL (Transmission Lost) khususnya pada dinding samping ruangan dengan menambahkan dinding ruang kelas C205 sebesar $5,4 \mathrm{~cm}$ untuk ruang kelas C208 sebesar 3,9 cm dan ruang kelas D207 sebesar 2,3 cm. dengan melihat tingkat kerapatan densitas diperoleh kecil maka menambahkan ketebalan dinding dapat dilakukan dengan cara melapisi ataupun mengisi dinding dengan bahan yang mampu mengisulasi suara.

\section{DAFTAR PUSTAKA}

Djunaedi, E. (2003). Akustik untuk Gedung Sekolah. Pikiran Rakyat, 30 Oktober 2003

Doelle, L Leslie. 1986. "Akustik Lingkungan”. Erlangga

Darmawan,K.Joestino dan H.Asmoro,W,A. "Desain Akustik Ruang Kelas Mengacu Pada Konsep Bangunan Hijau”. Fakultas Teknologi Industri, Institut Teknologi Sepuluh November, Surabaya.

Ernaning Setiyowati. "Pengaruh Bentuk Arsitektur Masjid Terhadap Kualitas Akustik Ruang".

Hananto S dan Busono T. 2009. Pengaruh kebisingan lalulintas terhadap efektivitas proses pembelajaran. Bandung: TERAS Jurnal Ilmiah Arsitektur Universitas Pendidikan Indonesia;

Keputusan Menteri Negara Lingkungan Hidup.1996."Baku Tingkat Kebisingan" Nomor:KEP-48/MENLH/II/1996. Mentri Negara Lingkungan Hidup.

Mediastika, E Christina. 2009. "Material Akustik Pengendali Kualitas Bunyi pada Bangunan". Yogyakarta.

Wardhana,W.A.2001. "Dampak Pencemaran Lingkungan”. Andi Offset. Jakarta 